\title{
Syntactic-Pragmatic Analysis of the Utterance of the Students to Their Lecturers Via Whatsapp
}

\author{
Tri Mastoyo Jati Kesuma ${ }^{1 *}$, Ike Revita ${ }^{2}$ \\ ${ }^{1}$ Universitas Gadjah Mada \\ ${ }^{2}$ Universitas Andalas \\ *Corresponding author. Email: t_mastoyo@ugm.ac.id
}

\begin{abstract}
The ways people communicate are delivering certain information. One of these ways is the use of sentence structure. Sentence structure is closely related to syntax, in which the elements of language are grammatically composed for certain intentions. This intention can be identified through a syntactic and pragmatic perspective. This article aims to describe the students' syntactic-pragmatic intention when they are communicating with the lecturers via social media WhatsApp. The data are the utterances used by some students from Gadjah Mada and Andalas University when communicating with their lecturers via WhatsApp. Note-taking and interviewing are the techniques used to collect the data. The analysis is done by using the concept of syntax by Verhaar [1] and Revita [2]. The result of the analysis is descriptively and narratively presented. Having analyzed the data, it is found that the students use some syntactic structures to deliver the intention to their lecturers via WhatsApp. They are incomplete sentences, grammatically incorrect sentences, and very simple sentences to create intimacy, highlight the intention, and force the lecturers to fulfil what they want.
\end{abstract}

Keywords: sentence, structure, syntactic-pragmatic, WhatsApp

\section{INTRODUCTION}

The use of the utterances syntactically acceptable does not only mean to fulfil the requirements of a grammatical rule but bearing a particular intention. It can be seen in how people use language in communication. The language usage follows the grammatical rules, but the variations of these rules have a specific meaning. For example, when the utterances comprise similar elements but are syntactically different, the purpose can be different.

(1) His desire is explicitly stated.

(2) His desire is stated explicitly.

Both utterances are composed of similar words but arranged differently. Utterance (1) has the adverb 'explicitly' before the verb 'stated,' and in utterance (2), the adverb comes after the verb. Semantically, the meaning is similar in that the speaker clearly and says what he wanted. However, when the two utterances are analyzed pragmatically, the speakers' intentions must not be the same. The first emphasized the adverb.

Meanwhile, the second highlighted the verb. The emphasis indicates the importance of the information. In pragmatics, such a strategy of choosing utterances delivers a particular intention. It is also called context [2]; [3].

Context is any background of the utterances in communication [6]; [4]; [2]; [5]. There are many aspects of context, including the choice of syntactical construction [7]; [9]. Pragmatic analysis that deals with this syntactical construction or the syntactical construction of language usage viewed from a pragmatic perspective are named syntactic-pragmatics.

The use of language in the current situation is very dynamic in the sense that communication may use various media. One of them is social media WhatsApp. WhatsApp is the message application provided by an android or smartphone that can send messages/text, pictures, files, sharing locations, and many others. WhatsApp can become a group or community of some people (maximally 250 numbers). Every member may chat in the group that other members can read that chat. Information can be easily shared via WhatsApp group because the sender does not need to send it one by one. The senders are only sending the information once for 250 people.

Even though the communication using WhatsApp is written down, many people in many domains keep using this application to communicate. For example, 
communication between lectures and their students. The information is sometimes shared via this WhatsApp. Surely, the lecturers designed a regulation to use WhatsApp in this context of interaction, like who can chat with the lecturers or when the chat can be conducted.

Even though the regulations are provided, some students still disobey them. Many students keep chatting with their lecturers at the wrong time and, ironically, with the wrong choice of words, incorrect grammatical construction, and impolite utterances. Some lecturers are sometimes tired of reading the way the students write the message. This writing describes how the students use the language (language usage) when they write a message to their lecturers via WhatsApp.

\section{METHOD}

The writing aims to explain the phenomena of language usage from the students to their lectures when they communicate via WhatsApp. The writing object is to identify the syntactic construction and pragmatic meaning of the chats from students to their lecturers. The data were taken from the chats of the researchers' students. They are from Gadjah Mada and Andalas University.

Data were any messages sent by the students to the researchers via WhatsApp from December 2019 until January 2020. Whether the data written in a local or foreign language is disobeyed because the focus is the syntactical construction. Data were collected by the observational method [10] with note-taking and interviewing techniques [7]. The interview was conducted with these students to dig the information about using syntactic construction in language usage.

The analysis used the pragmatic identity method and distributional method 10] by using the concept proposed by Mastoyo [7] and Revita [2]. The result of the analysis is descriptively done. The table and the chart and the percentage are used to clarify the number of syntactical construction used by the students.

\section{ANALYSIS}

The creativity of humans is in line with the dynamicity of language usage. Syntactically, various sentences are created by people when they interact using social media such as WhatsApp. It also happens to Gadjah Mada and Andalas University students when they interact with their lecturers via WhatsApp. They creatively write the message. Some grammatical regulations were disobeyed, like incomplete sentences, grammatically incorrect sentences, and very simple sentences. It should deliver a certain intention pragmatically, such as creating intimacy, highlighting the intention, and forcing the lecturers to fulfil what they want. The description of each way of the students is seen in the following explanation.

\section{Incomplete Sentence}

Greeting via WhatsApp is included in simple sentences [11]. In a simple speech, sentences are often incomplete. It can be seen in the following examples.

(3) Di jurusan, Bunda?

'In your department, Mam?'

(4) Kuliah bimbingan Senin tu Buk? 'Supervising on that Monday, Mam?'

(5) (Maaf pak saya lupa bawa laptop.) Rumah saya jauh Pak di Kalasan jika balik lagi. '(I am sorry, Sir. I forgot to bring my laptop). My home is far from here, Sir. It is in Kalasan.'

Sentence (3)-(5) is a form of interrogative and incomplete yet. Thus, the sentences can only be understood by those who have an understanding of the context. The sentences can be more understandable as the elements of the sentence are complete.

(3a) Apakah saya bisa bertemu di jurusan Bunda?

'Will I see you at our department, Mam?

(4a) Bisakah saya kuliah bimbingan (pada hari) Senin itu Buk?

'May I see you for supervising on that Monday, Mam?'

(5a) (Maaf pak saya lupa bawa laptop.) Rumah saya jauh Pak, yaitu di Kalasan, jika balik lagi ambil laptop.

'(I am sorry, Sir. I forgot bringing my lapop). My home is far from here. It is in Kalasan. It will take very long time if I have to go back.'

The presence of elements in bold italics in (3a)(5a) makes the context of the sentence clear. Surely, in the pragmatic realm, the completeness of the sentence elements is not the only determinant of the delivery of information.

The above examples (3) - 5) indicated that the gaining of the intention of an utterance pragmatically is more important than completeness. Making the utterances ore complete is required when there is the potential of having miscommunication.

(6) Bunda, bisa di jurusan? 'Mom, could it be at the department room?'

Utterance (6) is an example of a sentence that is very difficult to understand. The utterance is of great possibility to have multi meanings. The hearer might clarify the intention of the speaker by asking 'What do you mean by 'can'? The utterance can be revised into:

(6a) Bunda, apakah bisa bertemu di jurusan? 'Mom, could we meet at the department?'

(6b) Bunda, apakah saya bisa menemui Bunda di jurusan?

'Mom, may I see you at the department?' 
(6c) Bunda, apakah saya bisa bertemu Bunda di Jurusan?

'Mom, Is it possible for me to meet you at the department?'

So, pragmatically, the intention of the utterance is more prioritized than completeness. As the hearers get the point of the utterances, there will be no more clarification even though they are delivered incompletely.

\section{Grammatically Incorrect Sentence}

The sentence structure in simple sentences often deviates from the correct Indonesian sentence structure (Poedjosoedarmo [11]). Examples are as follows.

(7) Dosen: Ini apa, Mas?

'What is it, Mas?'

Mahasiswa: Maaf pak, ada yang saya bisa bantu.

'Excuse me, Sir. What could I do for you?'

(8) Ke kampus Ibuk Senin, Buk?

'Are you going to campus on Monday, Mam?'

The sentence structures (7) and (8) deviate from the correct sentence structure rules. Sentence (7) is a pronounced passive sentence. According to Kridalaksana [12], the pronominal passive sentence arrangement pattern is the aspect (bisa) + actor (saya) + verb (menolong). Therefore, the correct order for sentence (7) is as follows.

(7a) Dosen: Ini apa, Mas?

'What is it, Mas?'

Mahasiswa: Maaf pak, ada yang bisa saya bantu.

'Excuse me, Sir. Could I do something for you?'

Meanwhile, sentence structure (8) is Predicate (ke kampus) - Subject (Ibu) - Time Signal/Adverb of time (Senin). Such arrangement is distorted because the correct sentence structure is that the subject of the sentence is always in front of or to the left of the predicate. So, the sentence structure (8) will be correct if it is changed to be as follows.

(8a) Ibuk ke kampus Senin, Buk?

'Are you going to campus on Monday, Mam?'

The tendency of the structure of language in WhatsApp is oral-like. The speaker tends to ignore grammar but just write as if they have direct or oral communication. For example:

(9) Untuk naskah jurnalnya apakah saya sudah bisa submit, Pak?

'Can I submit the manuscript, Sir?'
(10) Selamat malam Pak, ini saya mengumpulkan tugas kelompok tadi pagi.

'Good evening, Sir. I submit the morning assignment.'

The utterance (9) and (10) are delivered in form of oral sentences that are written. What the speakers mean can be gained but disobey the grammar. Utterance (9) puts the right subject in the wrong position. The subject untuk naskah jurnalnya cannot be located at the beginning or before saya sudah bisa submit. In Bahasa Indonesia, the function of Subject cannot be put at previously. The structure will be grammatically acceptable assudah bisa saya submit [12]. The correct utterance is:

(9a) Naskah jurnalnya apakah sudah bisa saya submit, Pak?

'Could I submit the manuscript, Sir?'

Moreover, the verb mengumpulkan 'to submit' in sentence (10) must be kumpulkan to make the sentence become

(10a) Selamat malam Pak, ini saya kumpulkan tugas kelompok pagi tadi.

'Good evening, Sir. I submit this morning assignment.'

\section{Very Simple Sentence}

Another trend of communicating via WhatsApp is that the sentences are very simple [8]. Poedjosoedarmo [11] states that sentences in short speech are usually single sentences. Examples are as follows.

(11) Ujian kolokium Yudi nanti jam 11, ya Bu. Ditunggu kehadiran ibu.

'My proposal examination will be at 11.00 AM, Mam. I wait for your coming.'

(12) Bu, tesis Mega sudah dikirim.

'Mam, my thesis had been sent.'

The sentences in examples (11) and (12) are all single sentences. The sentence for Ujian kolokium Yudi nanti jam 11, ya Bu. Ditunggu kehadiran ibu is a single sentence with the structure of Subject (Ujian kolokium Yudi) - Predicate (nanti) - Adverb of time (jam 11). The sentence Ditunggu kehadiran ibu is single in the structure of Predicate (tunggu) - Subject (kehadiran $\mathrm{Ibu}$ ). Sentence Bu, tesis Mega sudah dikirim is a single sentence with the structure of Subject (tesis Mega) Predicate (dikirim). Pragmatically, sentences in the form of a single are more effective than complex sentences. 


\section{CONCLUSION}

In communicating via WhatsApp with lecturers, students turned out to be more concerned with delivering messages than good and correct language rules. As a result, the use of speech that is incomplete, not grammatical, and the structure deviates from the rules of correct sentence structure is a common thing in greeting via WhatsApp. Thus, pragmatically, the phenomenon implies a tendency to simplify the language used in social media. Moreover, the simplification reflects the current ways the students view the appropriateness of using language in communication. Simple sentences might be regarded as more practice even it is disobedience to the grammatically correct sentences.

\section{REFERENCES}

[1] Verhaar, J.W.M. (1996). Asas-Asas Linguistik Umum. Yogyakarta: Gadjah Mada University Press.

[2] Revita, Ike. (2013). Pragmatik:Kajian Tindak Tutur Permintaan Lintas Bahasa. Padang: Fakultas Ilmu Budaya Universitas Andalas.

[3] Revita, Ike. (2018). Kaleidoskop Linguistik . Padang: CV. Rumahkayu Pustaka Utama.

[4] Revita, Ike. (2008). "Permintaan dan Penolakan: Kajian Sosiopragmatik". Dissertation. Yogyakarta: Universitas Gadjah Mada.

[5] Revita, Ike, Trioclarise, R., \& Anggreiny, N. (2017). "Psychopragmatic Analysis Of Speech Act Of The Perpetrators Of The Violence Toward Minangkabau Women Analisis Psikopragmatik Tindak Tutur". Gramatika, 1(1962), pp. 112-121. https://doi.org/https://doi.org/10.21009/BAHTER A.161.

[6] Wijana, I Dewa Putu. (1996). Dasar-Dasar Pragmatik. Yogyakarta: Andi.

[7] Mastoyo, Tri Jati Kesuma. (2007). Pengantar (Metode) Penelitian Bahasa. Yogyakarta: Çarasvatibooks.

[8] Mastoyo, Tri Yohanes. (2015). "Struktur Peran dalam Klausa Bahasa Indonesia". Dissertation. Yogyakarta: Faculty of Cultural Sciences, Universitas Gadjah Mada.

[9] Kroeger, P. R. (2005). Analyzing Grammar: An Introduction. Cambridge: Cambridge University Press.

[10] Sudaryanto. (2015). Metode dan Aneka Teknik Analisis Bahasa: Pengantar Penelitian Wahana Kebudayaan secara Linguistis. Yogyakarta: Sanata Dharma University Press.

[11] Poedjosudarmo, Soepomo. (1980). "Tutur Ringkas Bahasa Indonesia". In Majalah Bahasa dan Sastra No. 2 Th. IV, pp. 27-28.
[12] Kridalaksana, Harimurti. (1975). "Beberapa Ciri Bahasa Indonesia Standar". In Pengajaran Bahasa dan Sastra Tahun 1 Nomor 1 1975, pp. $15-18$. 